\title{
Stimulation of the reproductive function of cows by kvatronan-Se preparation and complexes of nanocarboxylates
}

\author{
M.O. Khomenko ${ }^{1}$, V.O. Trokoz ${ }^{1}$, I.P. Chumachenko' ${ }^{1}$, M.V. Seba ${ }^{1}$, V.G. Kaplunenko ${ }^{2}$ \\ ${ }^{1}$ National University of Life and Environmental Sciences of Ukraine, Kyiv; \\ ${ }^{2}$ «Nanomaterials and Nanotechnologies»Ltd., Kyiv, Ukraine; e-mail: marina.homenko@ukr.net
}

\begin{abstract}
There was researched the effect of the kvatronan-Se preparation and two complexes of nanocarboxylates on the reproductive function of cows, in particular their fertility, biochemical and hormonal status. For experimental research, there were formed four groups of cows - the control group included intact animals and three experimental ones. The cows of the $1^{\text {st }}$ experimental group were subcutancously injected with a complex of nanocarboxylates $\mathrm{Se}, \mathrm{Cu}, \mathrm{Mn}, \mathrm{Cr}$; of the $2^{\text {nd }}$ group - with kvatronan-Se preparation; of the $3^{\text {rd }}$ - with $\mathrm{Ge}, \mathrm{Cu}, \mathrm{Mn}, \mathrm{Cr}$. It has been found that kvatronan-Se injections ( $2^{\text {nd }}$ experimental group) on the 10-12 th day of the sexual cycle increases the fertility of cows by 27.3; (compared with the control); by 18.2 and $9.0 \%$, respectively, compared to the $1^{\text {st }}$ (complex of $\mathrm{Se}, \mathrm{Cu}, \mathrm{Mn}, \mathrm{Cr}$ ) and $2^{\text {nd }}$ experimental group ( $\mathrm{Ge}, \mathrm{Cu}, \mathrm{Mn}, \mathrm{Cr}$ ). It should be noted that the specified preparation and complexes of nanocarboxylates with microelements stimulate metabolic processes in the body of animals. For example, on the $13^{\text {th }}$ day of sexual cycle the glucose content increased in experimental groups: in the $1^{\text {st }}$ group by 7.6; $2^{\text {nd }}-14.2$; $3^{\text {rd }}-4.5 \%$; the leved inereased cholesterol by 15.2; 15.6; $14.5 \%$, respectively. Concentration of total protein in the second group increased by 30.75 , in the $3^{\text {rd }}$ group $-2.60 \%$. In the group $1^{\text {st }}$ they observed the tendency to a decrease by $2.1 \%$. It has been established that kvatronan-Se preparation and the complex of $\mathrm{Ge}, \mathrm{Cu}, \mathrm{Mn}$, Cr promote the synthesis of sex hormones, such as progesterone, which level in these groups increased by 20.3 and $16.9 \%$ on the $13^{\text {th }}$ day of the sexual cycle. Dynamics of estradiol and testosterone concentration in all experimental groups did not change significantly. Therefore, kvatronan-Se is the most effective preparation in stimulating the reproductive function of cows, and changes that occur in the body of animals are considered to be favorable for implantation of the embryo.

Key words: nanocarboxylates; reproductive function; cows; fertility; progesterone; testosterone; biochemical parameters; cholesterol; kvatronan-Se.
\end{abstract}

\section{INTRODUCTION}

The problem of the low level of reproduction of cows is always relevant. Therefore, the issue of the need for hormones, prostaglandins, and biologically active preparation to regulate and stimulate reproductive function of females remains open. The main purpose of stimulation of the reproductive function of females is to promote the normalization of sexual cycle, which, after insemination, should be completed by an egg fertilization and embryo implantation with the subsequent birth of offspring.

Today, many methods of stimulating the sexual function of animals are known [1]. One of them is the use of hormonal drugs for correction of the sexual cycle. Natural and synthetic hormones have long been used in the practice of biotechnology for the reproduction of animals [2]. The disadvantage of these drugs after stimulating the sexual function is that they can lead to a disruption of the hormonal status of animals, as well as to lower the quality of milk and meat. With regard to these issues, new methods of correction of reproductive function of cows and heifers, which ensure the high efficiency, safety and ecological purity of livestock products, are used [3]. The top priority are those methods that

(C) M.O. Khomenko, V.O. Trokoz, I.P. Chumachenko, M.V. Seba, V.G. Kaplunenko 
are more natural and do not create a significant load on the body of animals in an intensive technology. These methods include the use of drugs that do not contain hormones for females in order to regulate the sexual function [4].

In modern veterinary medicine and biotechnology, there is a growing interest in the development of preparation, which include macroand microelements, which play an important role in maintaining the body homeostasis. It has been found, that surplus, deficiency or imbalance of macro- and microelements leads to a decrease in productivity and reproductive ability, metabolic processes, and various diseases [5]. This is due to the fact that minerals are not only structural material in the body, they also affect and provide the necessary conditions for the functioning of vitamins, enzymes; are involved into the digestion, synthesis of substances; affect the blood elements; have the ability to increase the activity of hormones, closely related to the activity of the ovaries, thyroid gland and pituitary gland [6, 7]. In addition, microelements play an important role in the enzymatic and many metabolic processes that are crucial for the embryo development $[7,8]$. According to this, the aim of the work was to study the effects of the kvatronan-Se preparation and complexes of nanocarboxylates of biogenic elements on the reproductive ability and related physiological changes in females.

\section{METHODS}

Nanocarboxylate complexes and the kvatronanSe preparation, which includes germanium nanocarboxylates, selenium, copper, manganese, chromium, and distilled water, were used for the study. The biotechnological process of manufacturing the preparation was carried out in accordance with the scheme: 1 - water preparation unit, 2 - reservoir for the storage of water prepared, 3 - reactor for colloidal solutions, 4 reservoir for the colloidal solutions accumulation, 5 - reactor for chemical transformations, 6 - reservoir for acid, 7 - automatic dispenser, 8 - mixing system of the components of the preparation, 9 - system of the preparation filtration, $10,11,12,13$ - chemical pumps of the blade type, 14, 15-machines for the preparation of packaging material, 16 - dosing device, 17 conveyor, 18 - packaging machine, 19 - system of thermoblocks.

The effect of substances under study on the reproductive function of females was examined in summer on cows of Ukrainian black-andwhite milk breed at "Dolynivske" Ltd. in Zhytomyr region. One control and three experimental groups of cows (500-550 kg of body weight, with an average annual milk yield of 60006260 $\mathrm{kg}$ ) were formed for the experiment. Animals showing signs of heat visually and rectally were further examined for the detection of mature follicles, and after the optimal time for insemination was determined. Cows of the control group were injected with isotonic sodium chloride solution; $1^{\text {st }}$ group - with complex of $\mathrm{Se}, \mathrm{Cu}, \mathrm{Mn}, \mathrm{Cr}$; $2^{\text {nd }}$ group - with kvatronan-Se preparation; in $3^{\text {rd }}$ experimental group - with $\mathrm{Ge}, \mathrm{Cu}, \mathrm{Mn}$ та Cr. All preparations were injected subcutaneously on the $10-12^{\text {th }}$ day of the sexual cycle at a dose of $0.02 \mathrm{ml} / \mathrm{kg}$. Pregnancy was determined rectally in 3 months after the insemination, and additionally - for the confirmation of the results ultrasound was performed.

To determine the biochemical and hormonal changes in animals after the use of kvatronan-Se preparation and complexes of nanocarboxylates, the following experiment was conducted. Each group included 5 cows by according to body weight, age, physiological state and productivity. Blood sample were taken from the caudal vein in the morning on the $9^{\text {th }}$ day of the sexual cycle before the use of the preparation, and on the $13^{\text {th }}$ day after it. Blood serum was obtained by sedimentation for 12 hours at room temperature. The formed supernatant was separated by centrifugation for 15 minutes. The serum obtained was frozen in a liquid nitrogen. The study on the biochemical composition of blood was carried out in the laboratory of the National Cancer Institute with the help of an automatic biochemical analyzer Vitros-250, USA using a 
reagent kit Ortho-clinical diagnostics.

Concentration of hormones was determined in the medical laboratory "Analityka" (Kharkiv) by immunochemiluminescence (immuno-CL) method with the help of the automatic analyzer Bioscience AIA-600 of the closed type, TOSOH (Japan), using the original Japanese reagents according to the instructions. The statistical processing of the experimental results was performed using Microsoft Excel 2007 software, and the probability of the difference was determined using Student's t criterion. Studies on animals were conducted in compliance with the principles of the European Convention for the Protection of Vertebrate Animals used for Experimental and other Scientific Purposes (Strasbourg, 1986).

\section{RESULTS AND THEIR DISCUSSION}

The results of the studies on the effectiveness of stimulation of cows fertilization after the insemination with nanocarboxylate complexes and kvatronan-Se preparation showed that the highest level of fertilization was observed in the $2^{\text {nd }}$ experimental group, where it significantly increased by $27.3 \%(\mathrm{P}<0.05)$, compared with the control group. In the $1^{\text {st }}$ and $3^{\text {rd }}$ experimental groups changes were statistics trialed insignificant it was 63.6 and $72.2 \%(\mathrm{P}>0.05)$, that is by $9.1(\mathrm{P}>0.05)$ and $17.7 \%(\mathrm{P}>0.05)$ higher than control, and by 18.5 and $9.6 \%(\mathrm{P}>0.05)$ lower than that in the $2^{\text {nd }}$ experimental group, respectively.

Biochemical analysis of the blood serum to determine the physiological mechanisms of regulating the reproductive ability of cows after the use of complexes of nanocarboxylates and the kvatronan-Se preparation (Table 1). The results of biochemical showed that the concentration of glucose, triglycerides, and creatinine in the blood of animals from the control group from the 9 th to the 13 th day of the sexual cycle changed only within $3 \%(\mathrm{P}>0.05)$. At the same

Table 1. Biochemical changes in serum of test cows before and after the use of nanocarboxylates and kvatronan-Se preparation $(\mathrm{M} \pm \mathbf{m}, \mathbf{n}=\mathbf{5})$

\begin{tabular}{|c|c|c|c|c|c|c|c|c|}
\hline \multirow{3}{*}{ Indicator } & \multirow{2}{*}{\multicolumn{2}{|c|}{ Control }} & \multicolumn{6}{|c|}{ Experimental groups } \\
\hline & & & \multicolumn{2}{|c|}{$\mathrm{Se}, \mathrm{Cu}, \mathrm{Mn}, \mathrm{Cr}$} & \multicolumn{2}{|c|}{ kvatronan-Se } & \multicolumn{2}{|c|}{$\mathrm{Ge}, \mathrm{Cu}, \mathrm{Mn}, \mathrm{Cr}$} \\
\hline & $9^{\text {th }}$ day & $13^{\text {th }}$ day & $9^{\text {th }}$ day & $13^{\text {th }}$ day & $9^{\text {th }}$ day & $13^{\text {th }}$ day & $9^{\text {th }}$ day & $13^{\text {th }}$ day \\
\hline \multirow[t]{2}{*}{ Glucose, $\mathrm{mmol} / \mathrm{l}$} & $3.06 \pm$ & $2.98 \pm$ & $3.18 \pm$ & $3.44 \pm$ & $3.0 \pm$ & $3.50 \pm$ & $3.18 \pm$ & $3.33 \pm$ \\
\hline & 0.141 & 0.150 & 0.170 & 0.140 & 0.34 & $0.081^{*}$ & 0.071 & 0.110 \\
\hline \multirow[t]{2}{*}{ Urea, $\mathrm{mmol} / \mathrm{l}$} & $3.74 \pm$ & $3.47 \pm$ & $3.2 \pm$ & $3.78 \pm$ & $3.62 \pm$ & $3.43 \pm$ & $3.6 \pm$ & $3.68 \pm$ \\
\hline & 0.160 & 0.120 & 0.19 & 0.371 & 0.210 & 0.250 & 0.14 & 0.170 \\
\hline \multirow{2}{*}{$\begin{array}{l}\text { Creatinine, } \\
\mu \mathrm{mol} / 1\end{array}$} & $76.6 \pm$ & $80.40 \pm$ & $72.25 \pm$ & $73.2 \pm$ & $80.6 \pm$ & $84.8 \pm$ & $77.2 \pm$ & $78.6 \pm$ \\
\hline & 3.231 & 2.910 & 2.861 & $2.94^{* *}$ & 3.04 & 2.82 & 3.02 & 3.96 \\
\hline \multirow{2}{*}{$\begin{array}{l}\text { Uric acid, } \\
\mu \mathrm{mol} / 1\end{array}$} & $146.8 \pm$ & $150.2 \pm$ & $147.25 \pm$ & $148.2 \pm$ & $161.4 \pm$ & $169.4 \pm$ & & $145.6 \pm$ \\
\hline & 10.29 & 5.67 & 7.390 & $3.20^{* *}$ & 2.01 & 6.70 & & 6.96 \\
\hline \multirow{2}{*}{$\begin{array}{l}\text { Cholesterol, } \\
\mathrm{mmol} / \mathrm{l}\end{array}$} & $4.16 \pm$ & $4.40 \pm$ & $4.66 \pm$ & $5.5 \pm$ & $5.03 \pm$ & $5.96 \pm$ & $4.84 \pm$ & $5.66 \pm$ \\
\hline & 0.441 & 0.531 & 0.450 & 0.241 & 0.260 & 0.661 & 0.410 & 0.302 \\
\hline \multirow{2}{*}{$\begin{array}{l}\text { Triglycerides } \\
\mathrm{mmol} / \mathrm{l}\end{array}$} & $0.28 \pm$ & $0.28 \pm$ & $0.45 \pm$ & $0.32 \pm$ & $0.34 \pm$ & $0.34 \pm$ & $0.38 \pm$ & $0.39 \pm$ \\
\hline & 0.071 & 0.021 & 0.071 & 0.051 & 0.051 & 0.051 & 2.550 & 81.061 \\
\hline \multirow[t]{2}{*}{ Total protein, g/l } & $76.02 \pm$ & $82.42 \pm$ & $82.26 \pm$ & $80.46 \pm$ & $78.36 \pm$ & $81.42 \pm$ & $78.94 \pm$ & $81.06 \pm$ \\
\hline & 2.820 & 5.310 & 0.710 & 2.720 & 2.610 & 1.640 & 2.550 & 1.860 \\
\hline
\end{tabular}

Note: $* \mathrm{P}<0.05$ compared to the control group

${ }^{* *} \mathrm{P}<0.05$ on the day 13 , compared to the second experimental group

$* * * \mathrm{P}<0.05$ compared to those indicators of the $9^{\text {th }}$ day 
time, the content of cholesterol and total protein increased on the $13^{\text {th }}$ day by $5.45(\mathrm{P}>0.05)$ and $7.70(\mathrm{P}>0.05)$, respectively; and the concentration of urea decreased by $7.20 \%(\mathrm{P}>0.05)$.

In group $1^{\text {st }}$ (complex of nanocarboxylates of $\mathrm{Se}, \mathrm{Cu}, \mathrm{Mn}$ and $\mathrm{Cr}$ ), the concentration of uric acid, creatinine, and total protein did not change during the experiment. The level of glucose, urea and cholesterol up to the $13^{\text {th }}$ day had a tendency to increase by $7.5 ; 15.0$, and $15.2 \%(\mathrm{P}>0.05)$, respectively. In the blood serum of cows in group $2^{\text {nd }}$ after three injections of kvatronan$\mathrm{Se}$, on the $10-12^{\text {th }}$ days after insemination, the concentration of glucose was $14.20(\mathrm{P}<0.05)$, creatinine $-4.95(\mathrm{P}>0.05)$; uric acid -4.70 $(\mathrm{P}>0.05)$; cholesterol - $15.60(\mathrm{P}>0.05)$; total protein $-3.75 \%(\mathrm{P}>0.05)$; and the urea content decreased by $5.20 \%(\mathrm{P}>0.05)$. Analysis of the indicators of group $3^{\text {rd }}$ shows, that after the use of the $\mathrm{Ge}, \mathrm{Cu}, \mathrm{Mn}$ and $\mathrm{Cr}$ complex from the $9^{\text {th }}$ to the $13^{\text {th }}$ day, the content of urea, creatinine, uric acid, total protein and triglycerols in the blood of animals changed slightly (within $3 \%$ ); and the concentration of cholesterol and glucose increased (tendency) by 14.48 and $4.50 \%$ $(\mathrm{P}>0.05)$, respectively.

Due to the fact that the highest fertility of cows was observed in the $2^{\text {nd }}$ group (kvatronan$\mathrm{Se})$, it was important to carry out a comparative analysis of biochemical changes in their blood with animals from the $1^{\text {st }}$ and the $3^{\text {rd }}$ experimental groups after the use of agents, and that is, on the $13^{\text {th }}$ day of the sexual cycle.

Early the embryo development and the hormone synthesis require a large amount of energy. Therefore, during the pregnancy, glucose levels increase due to the activation of energy metabolism [9]. The results of the analysis indicate that the $2^{\text {nd }}$ group had the highest level of glucose, which was by 1.7 and $4.8 \%(\mathrm{P}>0.05)$ higher than in those the $1^{\text {st }}$ and $3^{\text {rd }}$ groups. Due to the fact that the difference between the level of this metabolite in the $1^{\text {ts }}$ and the $2^{\text {nd }}$ group was only $1.7 \%(\mathrm{P}>0.05)$, the can assume that the increase in glucose concentration was due to the presence of selenium in the applied preparation (group $2^{\text {nd }}$ ) and in the complex (group $1^{\text {st }}$ ). This may be explained by selenium participation in glucose metabolism through selenoproteins, having a redox potential. Se-dependent proteins are believed to influence the release and signaling of insulin, and they are regulated by the oxidativereducing potential $[10,11]$. Such changes can contribute to implantation and preservation of the embryo, as the synthesis of hormones and the development of the fetus require a large amount of energy.

Metabolites that represent protein metabolism, include creatinine, uric acid, urea, and total protein. Creatinine content in the blood was $84.8 \mu \mathrm{mol} / 1$ in the $2^{\text {nd }}$ group, and exceeded the index of the $1^{\text {st }}$ and the $3^{\text {rd }}$ groups by 13.7 and $7.3 \%(\mathrm{P}>0.05)$, respectively. An increase in the concentration of this metabolite may be caused by a more intense metabolism of creatine, which amount apparently increases with high use of ATP. In addition, in this group the increase in the content of uric acid was 12.5 and $14 \%(\mathrm{P}>0.05)$, respectively. At the same time, the level of urea, on the contrary, tended to decrease by $9.3 \%(\mathrm{P}>0.05)$ and $6.8 \%(\mathrm{P}>0.05)$. Significant changes in the dynamics of total protein concentration in cows' blood samples in experimental groups after the use of kvatronanSe and complexes of nanocarboxylates were not observed; the difference was within $1 \%$, which is within the norm.

Cholesterol is one of the most important metabolites that plays an important role in reproduction and is an indicator of lipid metabolism in the body. A comparative analysis showed that its level in the second group was $5.96 \mathrm{mmol} / 1$, which was by $7.7 \%(\mathrm{P}>0.05)$ and $5,0 \%(\mathrm{P}>0.05)$ higher than in the first and third groups. This may indicate the stimulation of the synthesis of steroid hormones that contribute to the fertilization of animals. When analyzing the dynamics of changes in cholesterol levels during the experimental period (from the $9^{\text {th }}$ to the $13^{\text {th }}$ days of the sexual cycle), it is evident that in all experimental groups it tended to increase. Such changes can be caused by manganese, which 
these complexes and the preparation contain. This microelement affects the processes of glucogenesis and is a coenzyme of dimethylphosphorus phosphate, which catalyzes the formation of farnesyl pyrophosphate by isopenthenylpyrrophosphate and geranyl pyrophosphate isomerization. This process is important in the biosynthesis of cholesterol [12].

The next step was to analyze the dynamics of aspartate aminotransferase (ASAT), alanine transaminase (ALT), alkaline phosphatase (ALP) and lactate dehydrogenase (LDH) in the serum of experimental cows on the $9^{\text {th }}$ and $13^{\text {th }}$ days of the sexual cycle, beacouse Kvatronan-Se and the complexes of nanocarboxylates include microelements which are enzymes catalysts in this form (Table 2). In group $2^{\text {nd }}$, the activity of LP increased significantly by 1.9 ; ASAT - by 10.9 ; ALT - 7.6 and LDH - by $4.3 \%(\mathrm{P}>0.05)$. After analyzing the enzymatic changes that occurred in the blood samples of the $3^{\text {rd }}$ group of animals, we found that ALAT activity increased by 5.7 $(\mathrm{P}>0.05) ; \mathrm{LF}-$ by $3.6(\mathrm{P}<0.05), \mathrm{LDH}-5.4 \%$ $(\mathrm{P}>0.05)$. At the same time, the activity of the ASAT tended to decrease by $15.9 \%(\mathrm{P}>0.05)$.

It is known that pregnancy period is characterized by the ratio of the concentration of steroid hormones, that affect the nature of parturition and postpartum period. The content and proportion of sex hormones in the blood varies depending on the physiological state [13]. The greatest influence on the course of pregnancy have progesterone and estradiol. The first is produced by the yellow body, which is formed after the ovulation at the place of the follicle. At this stage, it is called the yellow body of the sexual cycle, which in the beginning of the pregnancy is transformed into a yellow body of pregnancy. This hormone regulates the main mechanisms of the embryo implantation, as well as the early stages of zygote development. In case of violation of its formation, the death of the embryo occurs, which is not recorded by specialists in early terms. Lack of progesterone can also lead to abortions. Its concentration in the blood of animals from the fourth day begins to increase and reaches its maximum in 10-12 days [14, 15].

When analyzing the dynamics of progesterone concentration from the $9^{\text {th }}$ to the $13^{\text {th }}$ day after the insemination, it is evident that its content in the blood of the cows of all four groups increased (Table 3). In the control group, on the $13^{\text {th }}$ day, the level of progesterone increased by $8.6(\mathrm{P}>0.05)$; in the $1^{\text {st }}$ experimental - by 10.4 $(\mathrm{P}>0.05)$; in the $2^{\text {st }}$ and $3^{\text {rd }}$ groups - by 20.3 $(\mathrm{P}<0,05)$ and $18.7 \%(\mathrm{P}<0,05)$, respectively. Therefore, the level of progesterone significantly increased in group $2^{\text {st }}$, where kvatronan-

Table 2. Enzymatic changes in serum of cows on the 9th and 13th day of the sexual cycle $(M \pm m, n=5)$

\begin{tabular}{|c|c|c|c|c|c|c|c|c|}
\hline \multirow{3}{*}{ Indicator } & \multirow{2}{*}{\multicolumn{2}{|c|}{ Control }} & \multicolumn{6}{|c|}{ Experimental groups } \\
\hline & & & \multicolumn{2}{|c|}{$\mathrm{Se}, \mathrm{Cu}, \mathrm{Mn}, \mathrm{Cr}$} & \multicolumn{2}{|c|}{ kvatronan-Se } & \multicolumn{2}{|c|}{$\mathrm{Ge}, \mathrm{Cu}, \mathrm{Mn}, \mathrm{Cr}$} \\
\hline & $9^{\text {th }}$ day & $13^{\text {th }}$ day & $9^{\text {th }}$ day & $13^{\text {th }}$ day & $9^{\text {th }}$ day & $13^{\text {th }}$ day & $9^{\text {th }}$ day & $13^{\text {th }}$ day \\
\hline $\begin{array}{l}\text { Aspartate } \\
\text { aminotrans- } \\
\text { ferase, cu/1 }\end{array}$ & $\begin{array}{c}61.8 \pm \\
4.35\end{array}$ & $\begin{array}{c}57.6 \pm \\
7.28\end{array}$ & $\begin{array}{c}60.28 \pm \\
1.910\end{array}$ & $\begin{array}{l}57 \pm \\
3.19\end{array}$ & $\begin{array}{c}60.2 \pm \\
3.84\end{array}$ & $\begin{array}{c}67.6 \pm \\
3.28\end{array}$ & $\begin{array}{c}65.2 \pm \\
2.82\end{array}$ & $54.8 \pm 2.22$ \\
\hline $\begin{array}{l}\text { Alanine } \\
\text { aminotrans- } \\
\text { ferase, cu/1 }\end{array}$ & $\begin{array}{l}30 \pm \\
2.07\end{array}$ & $\begin{array}{c}32.2 \pm \\
1.32\end{array}$ & $\begin{array}{l}45.6 \pm \\
4.61 *\end{array}$ & $\begin{array}{l}36 \pm \\
2.91\end{array}$ & $\begin{array}{c}38.6 \pm \\
4.51\end{array}$ & $\begin{array}{c}41.8 \pm \\
7.04\end{array}$ & $\begin{array}{l}32.6 \pm \\
15.90\end{array}$ & $34.6 \pm 1.86$ \\
\hline $\begin{array}{l}\text { Alkaline phos- } \\
\text { phatas, cu/l }\end{array}$ & $\begin{array}{l}75.2 \pm \\
6.23\end{array}$ & $\begin{array}{c}69.6 \pm \\
3.30\end{array}$ & $\begin{array}{l}57.8 \pm \\
14.27\end{array}$ & $\begin{array}{l}67.8 \pm \\
13.66\end{array}$ & $\begin{array}{l}50.2 \pm \\
3.58^{*}\end{array}$ & $\begin{array}{l}51.2 \pm \\
3.99 *\end{array}$ & $\begin{array}{l}90.2 \pm \\
20.26\end{array}$ & $93.6 \pm 5.33 *$ \\
\hline $\begin{array}{l}\text { Lactate } \\
\text { dehydroge- } \\
\text { nase, cu/1 }\end{array}$ & $\begin{array}{c}1664.6 \pm \\
27.11\end{array}$ & $\begin{array}{c}1585.6 \pm \\
93.01\end{array}$ & $\begin{array}{c}1670.8 \pm \\
61.80\end{array}$ & $\begin{array}{c}1673.6 \pm \\
81.01\end{array}$ & $\begin{array}{c}1622.8 \pm \\
38.63\end{array}$ & $\begin{array}{c}1696 \pm \\
89.65\end{array}$ & $\begin{array}{c}1605.8 \pm \\
52.71\end{array}$ & $1697.8 \pm 93.30$ \\
\hline
\end{tabular}


Table 3. The content of hormones in the blood of test heifers $(M \pm m, n=5)$

\begin{tabular}{|c|c|c|c|c|c|c|c|c|}
\hline \multirow{3}{*}{ Indicator } & \multirow{2}{*}{\multicolumn{2}{|c|}{ Control }} & \multicolumn{6}{|c|}{ Experimental groups } \\
\hline & & & \multicolumn{2}{|c|}{$\mathrm{Se}, \mathrm{Cu}, \mathrm{Mn}, \mathrm{Cr}$} & \multicolumn{2}{|c|}{ kvatronan-Se } & \multicolumn{2}{|c|}{$\mathrm{Ge}, \mathrm{Cu}, \mathrm{Mn}, \mathrm{Cr}$} \\
\hline & $9^{\text {th }}$ day & $13^{\text {th }}$ day & $9^{\text {th }}$ day & $13^{\text {th }}$ day & $9^{\text {th }}$ day & $13^{\text {th }}$ day & $9^{\text {th }}$ day & $13^{\text {th }}$ day \\
\hline \multirow{2}{*}{ Progesterone, $\mathrm{ng} / \mathrm{ml}$} & $3.28 \pm$ & $3.59 \pm$ & $3.36 \pm$ & $3.75 \pm$ & $3.26 \pm$ & $4.09 \pm$ & $3.28 \pm$ & $3.95 \pm$ \\
\hline & 0.381 & 0.554 & 0.275 & 0.441 & 0.256 & $0.254 * * *$ & 0.319 & $0.691 * * *$ \\
\hline Estradiol, pg/ml & $\begin{array}{c}17.08 \pm \\
1.659\end{array}$ & $\begin{array}{c}16.84 \pm \\
0.863\end{array}$ & $\begin{array}{c}16.71 \pm \\
1303\end{array}$ & $\begin{array}{c}16.28 \pm \\
1237\end{array}$ & $\begin{array}{c}16.89 \pm \\
1353\end{array}$ & $\begin{array}{c}16.40 \pm \\
1.167\end{array}$ & $\begin{array}{c}16.75 \pm \\
1.466\end{array}$ & $\begin{array}{c}16.27 \pm \\
0.969\end{array}$ \\
\hline \multirow{2}{*}{ Testosterone, $\mathrm{ng} / \mathrm{ml}$} & $3.16 \pm$ & $3.21 \pm$ & $3.13 \pm$ & $3.20 \pm$ & $3.29 \pm$ & $3.29 \pm$ & $3.24 \pm$ & $3.28 \pm$ \\
\hline & 0.328 & 0.265 & 0.441 & 0.301 & 0.693 & 0.572 & 0.480 & 0.520 \\
\hline
\end{tabular}

Se was used. The largest number of calvers was found to be in this group as well. The progesterone precursor is cholesterol. According to the experimental studies presented above, it was found that the preparation contributes to increase in the content of this metabolite, from which pregnenolone is formed.

Basing on the said above, one can assume that the action of copper and chromium, which are components of the preparation, the activity of insulin increases, and this stimulates the activity of the pituitary gland; and, as a result, increases the level of luteinizing hormone (LH). Under the influence of $\mathrm{LH}$, pregnenolone is transformed into 17-hydroxypregnenolon and progesterone, which are further transformed into estrogens and testosterone [16]. The main and most active estrogen is estradiol, and its intermediate product is testosterone [17]. The concentration of estradiol at the beginning and the middle of pregnancy is low, and it increases before parturition [13]. On the contrary, the dynamics of the concentration of estradiol, from the $9^{\text {th }}$ to the $13^{\text {th }}$ day tended to decrease: in the control group by 1.4 ; in $1^{\text {st }}, 2^{\text {nd }}$ and $3^{\text {rd }}$ experimental - by $2.5 ; 2.9$ and $2.8 \%$ $(\mathrm{P}>0.05)$, respectively. The next hormone, which content was determined in blood serum of heifers, was testosterone. In females, this hormone and its precursors are synthesized at significantly lower concentrations than in males. Testosterone is transformed into estrogen in ovaries [15]. Analysis of testosterone concentration in heifers' blood shows, that in the control group, $1^{\text {st }}$ and $2^{\text {nd }}$ experimental ones, on the $13^{\text {th }}$ day after the insemination, there was a slight increase in the latter within $2 \%(\mathrm{P}>0.05)$. In the $2^{\text {nd }}$ group, this indicator did not.

For better analysis, we compared the index of hormones between groups on the $13^{\text {th }}$ day of the sexual cycle. The level of progesterone in the control group from the $9^{\text {th }}$ to the $13^{\text {th }}$ day increased by 8.6 ; in the $1^{\text {st }}$ experimental - by $10.4(\mathrm{P}>0.05) ; 2^{\text {nd }}-20.3(\mathrm{P}<0.05), 3^{\text {rd }}-16.9 \%$ $(\mathrm{P}>0.05)$. The highest progesterone content was in the blood of cows of the $2^{\text {nd }}$ experimental group, which was $4.09 \mathrm{ng} / \mathrm{ml}$; that was by $12.2 \%$ $(\mathrm{P}>0.05)$ higher compared to the control group, and by $8.3 \%$ and $3.4 \%(\mathrm{P}>0.05)$ compared to the $1^{\text {st }}$ and $3^{\text {rd }}$ experimental groups, respectively. Due to the increase in the concentration of progesterone during this period, the myometrial excitability decreases and its contractile activity is suppressed. In addition, this hormone blocks the immune response of the mother organism to the embryo and thus, creates favorable conditions for its development. The fertility indicators in the second experimental group evidence this. Based on the data presented, the concentration of estradiol in the blood serum of test heifers in all four groups had a slight variation within $3 \%(\mathrm{P}>0.05)$. 


\section{CONCLUSIONS}

The use of nanocarboxylates in livestock is a promising area of research. It has been found, that the highest level of fertilization is observed in the group of animals, where the kvatronanSe preparation is used on the $10-12^{\text {th }}$ days of the sexual cycle. The indicators here are higher by $20.3 \%(\mathrm{P}<0.05)$, compared to the control. In addition, the preparation and complexes of nanocarboxylates with microelements intensify protein, carbohydrate, and lipid metabolism in experimental animals. The results of the biochemical study indicate that glucose levels increases by $14.2(\mathrm{P}<0.05)$; cholesterol - by 5.2 , and total protein - by $3.7 \%(\mathrm{P}>0.05)$ in the blood serum of cows after the use of kvatronanSe preparation on the 13th day of the sexual cycle. The complex of nanocarboxylates containing $\mathrm{Se}, \mathrm{Cu}, \mathrm{Mn}, \mathrm{Cr}$ contributes to an increase in the glucose and cholesterol concentration in the serum by 7.50 and $15.27 \%(\mathrm{P}>0.05)$, respectively; while the complex of $\mathrm{Ge}, \mathrm{Cu}, \mathrm{Mn}, \mathrm{Cr}$ increases their concentration by 4.5 and $14.48 \%$ $(\mathrm{P}>0.05)$, respectively. Therefore, we consider that nanocarboxylates with microelements, in kvatronan-Se preparation and complexes that are involved in the synthesis of steroid hormones, lead in of to an increase in the level of progesterone by $10.4-20.3 \%(\mathrm{P}>0.05)$.

The authors of this study confirm that the research and publication of the results were not associated with any conflicts regarding commercial or financial relations, relations with organizations and/or individuals who may have been related to the study, and interrelations of coauthors of the article.

\section{М.О. Хоменко ${ }^{1}$, В.О. Трокоз ${ }^{1}$, І.П. Чумаченко ${ }^{1}$, М.В. Себа ${ }^{1}$, В.Г. Каплуненко \\ СТИМУЛЯЦІЯ РЕПРОДУКТИВНОЇ ФУНКЦЇ̈ КОРІВ ПРЕПАРАТОМ КВАТРОНАН-SЕ ТА КОМПЛЕКСАМИ НАНОКАРБОКСИЛАТІВ}

Досліджено вплив препарату кватронан-Se та двох комплексів нанокарбоксилатів на репродуктивну функцію корів, зокрема їх заплідненість, біохімічний і гормональний статус. Для проведення експериментальних досліджень було сформовано чотири групи корів контрольну, до якої увійшли інтактні тварини, і три дослідні. Коровам I дослідної групи підшкірно вводили комплекс нанокарбоксилатів $\mathrm{Se}, \mathrm{Cu}, \mathrm{Mn}, \mathrm{Cr}$; II дослідній - препарат кватронан-Se; III - Ge, $\mathrm{Cu}, \mathrm{Mn}$ та Cr. Встановлено, що уведення кватронану-Se на 10-12-ту доби статевого циклу підвищує заплідненість корів на 27,3 порівняно з контрольною, 18,2 та 9,0 \%, відповідно, з I ( $\mathrm{Se}, \mathrm{Cu}, \mathrm{Mn}, \mathrm{Cr})$ та III дослідною групою $(\mathrm{Ge}, \mathrm{Cu}, \mathrm{Mn}, \mathrm{Cr})$. Також, слід відмітити, що вказаний препарат та комплекси нанокарбоксилатів мікроелементів стимулюють метаболічні процеси в організмі тварин: у дослідних групах відмічено на 13-ту добу статевого циклу підвищення вмісту глюкози на 7,6, 14,2, 4,5 \% у I, II, та III групах відповідно; холестерину - на 15,2, 15,6, 14,5 \% відповідно. Концентрація загального білка у ІІ групі зросла на 3,75, III - 2,60 \%. У I групі спостерігали тенденцію до зниження показника на 2,1%. Встановлено, що препарат кватронан-Se та комплекс $\mathrm{Ge}, \mathrm{Cu}, \mathrm{Mn}, \mathrm{Cr}$ сприяють синтезу статевих гормонів, а саме прогестерону, вміст якого на 13-ту добу статевого циклу вірогідно підвищився у цих групах на 20,3 та 16,9\%. Динаміка концентрації естрадіолу і тестостерону у всіх дослідних групах вірогідно не змінилася. Отже, препарат кватронан-Se $\epsilon$ найбільш ефективним для стимуляції репродуктивної функції корів, а зміни, які відбуваються в організмі тварин, сприятливі для імплантації ембріона.

Ключові слова: нанокарбоксилати; відтворювальна здатність; корови; заплідненість; прогестерон; тестостерон; біохімічні показники; холестерин; кватронан-Se.

${ }^{1}$ Національний університет біоресурсів $i$ природокористування України, Київ;

${ }^{2}$ ТОВ «Наноматеріали і нанотехнологї̈», Київ; e-mail: marina.homenko@ukr.net

М.А. Хоменко ${ }^{1}$, В.А. Трокоз ${ }^{1}$, И.П. Чумаченко ${ }^{1}$, Н.В. Себа ${ }^{1}$, В.Г. Каплуненко ${ }^{2}$

\section{СТИМУЛЯЦИЯ РЕПРОДУКТИВНОЙ ФУНКЦИИ КОРОВ ПРЕПАРАТОМ КВАТРОНАН-SЕ И КОМПЛЕКСАМИ НАНОКАРБОКСИЛАТОВ}

Исследовано влияние препарата кватронан-Se и двух комплексов нанокарбоксилатов на репродуктивную функцию коров, в частности их оплодотворяемость, биохимический и гормональный статус. Для проведения экспериментальных исследований были сформированы четыре группы коров - контрольную, в которую вошли интактные животные, и три опытных. Коровам I опытной группы подкожно вводили комплекс нанокарбоксилатов $\mathrm{Se}, \mathrm{Cu}, \mathrm{Mn}, \mathrm{Cr}$; II опытной - препарат кватронан$\mathrm{Se}$; III - Ge, Cu, Mn и Cr. Установлено, что введение кватронану-Se на 10-12е сутки полового цикла повышает 
оплодотворяемость коров на 27,3, по сравнению с контролем, 18,2 и 9,0\%, соответственно, с I ( $\mathrm{Se}, \mathrm{Cu}, \mathrm{Mn}, \mathrm{Cr})$ и III исследовательской группой ( $\mathrm{Ge}, \mathrm{Cu}, \mathrm{Mn}, \mathrm{Cr})$. Также, следует отметить, что указанный препарат и комплексы нанокарбоксилатов микроэлементов стимулируют метаболические процессы в организме животных: в опытных группах отмечено на 13-е сутки полового цикла повышения содержания глюкозы на 7,6, 14,2, 4,5% в I, II, и III группах соответственно; холестерина на 15,2, 15,6, $14,5 \%$ соответственно. Концентрация общего белка во II группе выросла на 3,75, III - 2,60 \%. В I группе наблюдалась тенденция к снижению показателя на 2,1 \%. Установлено, что препарат кватронан-Sе и комплекс $\mathrm{Ge}, \mathrm{Cu}$, $\mathrm{Mn}, \mathrm{Cr}$ способствуют синтезу половых гормонов, а именно прогестерона, уровень которого на 13-е сутки полового цикла достоверно повысился в этих группах на 20,3 и $16,9 \%$. Динамика концентрации эстрадиола и тестостерона во всех опытных группах достоверно не изменилась. Итак, препарат кватронан-Sе является наиболее эффективным для стимуляции репродуктивной функции коров, а изменения, которые происходят в организме животных, благоприятные для имплантации эмбриона.

Ключевые слова: нанокарбоксилаты; воспроизводящая способность; коровы; оплодотворенность; прогестерон; тестостерон; биохимические показатели; холестерин; кватронан-Se.

\section{REFERENCES}

1. Bodnar OO. Development of complex charts renewal and stimulation of the reproduced function of sows. Scientific Journal of Veterinary Medicine 2010; 6 (79): 30-2. [Ukrainian].

2. Grischuk GP. The influence of photoplacenate and estrophan on the reproductive function of cows. Vet Med Ukraine. 2012; 2 (192): 21-3. [Ukrainian].

3. Ryabukha VA, Muller TV, Ostikova ME. Morphology of biologically active points of large tuber and their stimulation of family by insemination. Scientific Herald of NULES of Ukraine. Series: Veterinary medicine, quality and safety of products of stock-raising. 2013; 188 (2): 141-4. [Ukrainian].

4. Spitsina TL, Rakityansky VM, Sukhin VM. Correction of physiological status and reproductive function of sows due to influence of biologically active additive. News of Poltava State Agrarian Academy. 2014; 1: 47-9. [Ukrainian].
5. Sakhanda IV, Polova ZhM. Relevance of pharmaceutical development of copper based drugs. Ukrainian scientific and medical youth magazine. The Ukrainian Scientific Medical Youth Journal 2014; 3: 138-40. [Ukrainian].

6. Kotsuruba AV, Kopjak BS, Sagach VF, Shcherbakov AV, Zholobak NM, Spivak NJA. Restoration of erythrocytes stability to acid hemolysis by cerium oxide nanoparticles in old rats. Fiziol Zh. 2014; 60(6): 3-9. [Ukrainian].

7. Hostetler C. Kincaid RL, Mirando MA. The role of essential trace elements in embryonic and fetal development in livestock. Vet J. 2003; 2: 125-39.

8. Nischemenko NP, Trokoz VO, Poroshynska OA, Stovbecka LS, Emelynenko AV, Emelynenko AA. The influence of nanoaquchelates of selenium, germanium and their complex on the embryonic development of quails. Fiziol Zh. 2018; 64(3): 30-6. [Ukrainian].

9. Semeronchik AD. Changes in glucose content in serum of cows during pregnancy and postpartum period. News of Poltava State Agrarian Academy. 2013; 3: 185-6. [Ukrainian].

10. Buhrov OD, Hmelkov MV. Early preimplantation embryonic mortality in heifers and cows. Scientific and technical bulletin AI NAAS. 2015; 113: 52-7. [Ukrainian].

11. Steinbrenner H. Interference of selenium and selenoproteins with the insulin-regulated carbohydrate and lipid metabolism. Free Radic Biol Med. 2013; 65: 1538-47.

12. Gubsky YuYuI. Biological chemistry: Manual. KyivTernopil: Ukrmedbook. 2000: 508. [Ukrainian].

13. Mann GE. Corpus luteum size and plasma progesterone concentration in cows. Anim Reprod Sci. 2009; 115: 296-9.

14. Vlasenko SA. Sex steroids of blood in cows with purulonecrotic lesions of lower limbs during the reproductive cycle. The Animal Biology. 2015; 17(4): 9-17. [Ukrainian].

15. Sheremeta VI, Bezverha LN, Seba MV, Trohymenko VZ. Reproduction function of females increases after injection of neurotrophic metabolic substances Glutam 1M. Fiziol Zh. 2017; 63(4): 72-9. [Ukrainian].

16. Gruntkovsky MS, Sheremeta VI, Kaplunenko VH. Reproductive ability of cows using drug nanovulin-VHR. Animal breeding and genetics. 2015; 49: 199-203. [Ukrainian].

17. Malogozhata S, Sapa YA. Progesterone - a new look at an old drug. J Reproduct Endocrinol. 2017; 1(33): 1725. [Russian].

\section{Received}

